\title{
PENGARUH DISPARITAS PENJATUHAN PIDANA TERHADAP PENANGGULANGAN TINDAK PIDANA KORUPSI DI INDONESIA
}

\author{
Irfan Ardiansyah \\ Advokat Kantor Hukum Irfan Ar Comel \& Partner \\ e-mail: irfanardiansyah@gmail.com
}

\begin{abstract}
Abstrak-Faktor-faktor yang menjadi pertimbangan hakim pada kasus tindak pidana korupsi sehingga menimbulkan disparitas putusan pidana meliputi factor; perundangundangan, pribadi hakim, dan lingkungan yang mencakup faktor politik dan ekonomi. Disparitas pidana tidak berpengaruh terhadap pemberantasan tindak pidana korupsi, dan konsep ideal agar tidak ada lagi disparitas pidana pada penjatuhan pidana tindak pidana korupsi dapat dilakukan dengan cara dibuatnya pedoman pemidanaan, mengkonstruksi kembali (rekonstruksi) pola pemikiran dan perilaku etik hakim, dan upaya untuk memutus perkara yang bebas tendensi.
\end{abstract}

\section{Kata Kunci: Hakim, Disparitas Putusan, Korupsi.}

Abstract-Factors those are considered by the judge in the criminal act on corruption cases which causes disparity in punishment, are as these matters; legislation factors, judge personal factors, and environmental factors which include political and economic factors. Criminal disparity does not affect the eradication of corruption, and the ideal concept in order to obviate the disparity on the criminal punishment of corruption, can be done by creating sentencing guidelines that can be used as a reference or guidelines for judges to impose criminal sanction, reconstructing (reconstruction) patterns of thought and ethical behavior of judges, and an attempt to break free cases tendencies.

Keywords: Judge, Verdict Disparity, Corruption.

\section{A. PENDAHULUAN}

Salah satu yang menjadi hambatan dalam penanganan kasus korupsi adalah timbulnya disparitas pidana dalam hal pemidanaannya. Permasalahan tersebut sumbernya adalah putusan hakim. Disparitas putusan hakim yang disatu sisi memberikan hukuman yang berat dan disisi lain memberi hukuman yang ringan, mengakibatkan kasus-kasus korupsi sulit untuk diberantas.
Kekuasaan Kehakiman sebagai suatu kekuasaan negara yang bebas dan merdeka di satu sisi membawa dampak yang sangat positif terhadap upaya penegakan hukum di Indonesia (Muladi, 2011:17). Dalam hal ini, hakim menjadi suatu badan yang independent dan putusannya tidak dapat dipengaruhi oleh badan-badan atau kekuasaan lain. Namun demikian, hakim tidak hidup di ruang hampa. Keputusannya meskipun tidak 
boleh dipengaruhi oleh badan-badan hukum atau kekuasaan lainnya, namun pada kenyataannya putusan hakim sangat dipengaruhi oleh latar belakang pendidikan, nilai moral, kebutuhan ekonomi, lingkungan pergaulan, dan sebagainya. Pengaruh tersebut pada akhirnya dapat mendistorsi keputusan hakim yang bersangkutan

(Kuntoro Mangkusubroto, 2013:16-18). Oleh karena itu di tengah masyarakat seringkali dikenal istilah putusan hakim berdasarkan "pesanan". Ironisnya "pesanan" ini justru seringkali berasal dari badan hukum lainnya atau dari oknum yang memegang kekuasaan (Kuntoro Mangkusubroto, 2013:16-18).

Kebebasan hakim dalam menjatuhkan putusannya ternyata juga membawa suatu dampak negatif yaitu munculnya disparitas pidana. Disparitas Pidana (disparity of sentencing) dalam hal ini adalah penerapan pidana yang tidak sama terhadap tindak pidana yang sama (same offence) atau terhadap tindaktindak pidana yang sifat berbahayanya dapat diperbandingkan (offences of comparable seriousness)
(Muladi dan Barda Nawawi Arief, 2012:26).

Disparitas (disparity: dis-parity) pada dasarnya adalah negasi dari konsep paritas (parity) yang artinya kesetaraan jumlah atau nilai. Dalam konteks pemidanaan paritas artinya adalah kesetaraan hukuman antara kejahatan serupa dalam kondisi serupa (Allan Manson, 2014:92-93). Dengan demikian disparitas adalah ketidaksetaraan hukuman antara kejahatan yang serupa (same offence) dalam kondisi atau situasi serupa (comparable circumstances) (Litbang Mahkamah Agung, 2011:6). Konsep disparitas ini sendiri tidak dapat dipisahkan dari prinsip proporsionalitas, prinsip pemidanaan yang diusung oleh Beccaria dimana diharapkan hukuman yang dijatuhkan kepada pelaku kejahatan proporsional dengan kejahatan yang dilakukannya (Allan Manson, 2014:82). Jika konsep paritas dan proporsionalitas ini dilihat dalam satu kesatuan maka, disparitas pemidanaan dapat terjadi juga dalam hal dijatuhinya hukuman yang sama terhadap pelaku yang melakukan kejahatan yang berbeda tingkat kejahatannya. 
Irfan Ardiansyah, Pengaruh Disparitas Penjatuhan Pidana Terhadap Penanggulangan Tindak....

Adanya perbedaan dalam ancaman pidana minimum khusus penjatuhan hukuman atau disparitas pemidanaan menjadi permasalahan ketika terjadi perbedaan hukuman yang dijatuhkan antara perkara yang serupa, sehingga dipandang menimbulkan ketidakadilan serta dapat menimbulkan kecurigaankecurigaan di masyarakat. Oleh karenanya, diskursus mengenai disparitas pemidanaan dalam ilmu hukum pidana dan kriminologi tidaklah pernah dimaksudkan untuk menghapuskan perbedaan besaran hukuman terhadap para pelaku kejahatan, namun memperkecil rentang perbedaan penjatuhan hukuman tersebut.

Di Indonesia, disparitas pemidanaan terkait perkara korupsi bukan hal baru. Boleh jadi, adanya disparitas pemidanaan dalam perkara korupsi merupakan salah satu faktor yang mendorong UU No. 3 Tahun 1971 tentang Pemberantasan Tindak Pidana Korupsi digantikan dengan UU No. 31 Tahun 1999. Dimana salah satu perubahan yang terjadi dalam UU No. 31 Tahun 1999 adalah perumusan ancaman hukumannya. Dalam UU No. 31 Tahun 1999, mulai diatur kembali, serupa dengan model pengaturan dalam Code Penal Napoleon.

Berdasarkan uraian di atas maka dapat dikatakan disparitas pidana dalam tindak pidana korupsi masih terjadi sampai sekarang. Adanya disparitas pidana dalam tindak pidana korupsi ini mengindikasikan bahwa pada penjatuhan putusannya hakim terpengaruh oleh berbagai kepentingan.

Namun saat ini masyarakat dibingungkan oleh berbagai perilaku hakim dan kualitas putusannya termasuk adanya disparitas putusan pidana dalam kasus-kasus korupsi. Adanya disparitas putusan hakim ini mengundang kritik dan sinisme, yang mengarah kepada ketidakpercayaan masyarakat, dan membentuk sikap skeptik cukup besar. Hal demikian muncul karena banyak hakim yang tidak serius, dan melakukan tindakan tidak terpuji, yaitu dengan menggadaikan martabat dan nama baiknya. Hal ini dijelaskan Satjipto Rahardjo "saat ini pengadilan berubah menjadi pasar yang 
memperdagangkan putusan, pengadilan terlalu sering mencoreng martabatnya sendiri, dan bersama sama dengan koruptor telah menjadi benalu di negeri ini” (Satjipto Rahardjo, 2011:90). Selanjutnya Rahardjo juga menyatakan, "Indonesia tengah dilanda krisis besar. Mahkamah Agung dan pengadilan-pengadilan di bawahnya mendapat sorotan yang sangat keras dari masyarakat dan tidak puas oleh putusan putusan yang dibuat serta perilaku para pejabat pengadilan (Satjipto Rahardjo, 2011:167-168).

Berdasarkan latar belakang yang telah dipaparkan di atas maka dapat diidentifikasi permasalahan yaitu faktor-faktor apa saja yang menjadi pertimbangan hakim dalam penjatuhan pidana pada kasus tindak pidana korupsi yang menimbulkan disparitas? Ada pengaruh disparitas pidana terhadap pemberantasan tindak pidana korupsi? Dan konsep ideal untuk meminimalkan adanya disparitas pidana pada penjatuhan pidana tindak pidana korupsi dikaitkan dengan rasa keadilan masyarakat Indonesia?
B. HASIL DAN PEMBAHASAN

1. Faktor-faktor yang Menjadi Pertimbangan Hakim dalam Penjatuhan Pidana pada Kasus Tindak Pidana Korupsi yang Menimbulkan Disparita

Hakim sesuai dengan tugas dan fungsinya serta Hakim dengan segala kewenangan yang dimilikinya merupakan aktor utama penyelenggara kekuasaan kehakiman dan sekaligus sebagai pengawal praktik penegakan hukum dan keadilan. Hakim melalui putusannya, dapat mengubah, mengalihkan, atau bahkan mencabut hak dan kebebasan warga negara, dan semua itu dilakukan dalam rangka menegakkan hukum dan keadilan (Rizky Argama, 2014). Dalam realitasnya menunjukkan upaya hakim untuk menegakkan hukum dan keadilan melalui putusannya tersebut bukanlah hal yang mudah (Esmi Warassih, 2013:10), Berbagai komentar dan pendapat baik yang berbentuk pandangan ataupun penilaian dari berbagai kalangan masyarakat selalu menghiasi media massa yang ada di Indonesia, terkait keputusan Majelis 
Irfan Ardiansyah, Pengaruh Disparitas Penjatuhan Pidana Terhadap Penanggulangan Tindak....

Hakim dalam menjatuhkan pidana terhadap para terdakwa khususnya pada kasus korupsi.

Menurut Magnis Suseno, sikap dan tindakan-tindakan yang harus diambil tidak berdiri di ruang kosong, melainkan harus dipertanggungjawabkan terhadap nilai-nilai kemanusiaan yang sebenarnya, terhadap tugas dan kewajiban dan terhadap orang lain. Sikap yang diambil secara bebas hanya memadai apabila sesuai dengan tanggung jawab obyektif itu (Franz Magnis Suseno, 2013:295). Dalam membuat putusan atas perkara yang ditangani harus bersumber pada kemapuan hakim untuk berpikir dan berkehendak secara bebas namun dalam dengan satu catatan bahwa apa yang sudah diputuskan harus dapat dipertanggung-jawabkan kepada masyarakat tanpa mengurangi nilai objektivitasnya.

Berdasarkan uraian di atas, maka dapat dikatakan bahwa faktorfaktor yang mempengaruhi putusan hakim antara lain (1) faktor pada undang-undang itu sendiri; (2) faktor intern; (3) faktor penafsiran; (4) faktor politik; dan (5) faktor sosial
(Loebby Loqman, 2012:100-101). Berdasarkan hal ini maka faktor undang-undang dapat menjadi pertimbangan hakim pada kasus tindak pidana korupsi sehingga menimbulkan disparitas putusan pidana. Berbagai pengaturan di dalam UUPTPK bukanlah tanpa kekurangan. Duplikasi pengaturan tindak pidana korupsi dan perumusan ancaman pidana menjadi dua persoalan yang mendukung lahirnya disparitas pemidanaandan inkonsistensi putusan dalam tindak pidana korupsi. Untuk menggambarkan masalah-masalah di atas, perlu ditunjukkan potret atas ketentuan korupsi di Indonesia, khususnya pengaturan dalam UUPTPK. Pembahasan berikut ini menggambarkan bagian kecil dari masalah dalam UUPTPK yang dirasa memberikan pengaruh besar atas lahirnya disparitas pemidanaan dan inkonsistensi putusan.

Selanjutnya faktor lain yang dapat menimbulkan disparitas putusan pidana adalah faktor keyakinan hakim. Keyakinan ini dipengaruhi faktor kepribadian yang ada di diri hakim seperti misalnya 
agama, pendidikan, nilai yang dianut dan moralitas serta mentalitas hakim. Selain itu keyakinan hakim juga dipengaruhi oleh lingkungan sosial (M. Syamsudin, 2012:95-98). Lingkungan sosial ini mencakup faktor politik, ekonomi, dan seterusnya. Seorang Hakim sangat sulit untuk secara sempurna menutup diri terhadap pengaruh faktor-faktor tersebut.

Dari faktor-faktor tersebut maka dapat dikatakan pada umumnya terjadinya disparitas putusan pidana khususnya dalam tindak pidana korupsi dipengaruhi oleh pola pikir hakim dan sistem nilai yang dianut hakim. Terkait pola pikir hakim, ada dua kecenderungan pola pikir hakim dalam menangani perkara korupsi, yaitu pertama pola pikir hakim yang bercorak positivistik dan kedua pola pikir hakim yang bercorak nonpositivistik. Pola pikir hakim dengan corak yang pertama sangat menekankan pada ukuran-ukuran formal teks aturan (aturan sentris) dalam menggali kebenaran hukum, sedangkan pola pikir dengan corak yang kedua mengelaborasikan teks aturan hukum dengan konteks sosio- legal (Sulistyowati Irianto dan Shidarta, 2012:173-175) dalam menggali kebenaran hukum (M. Syamsudin, 2011:510).

Faktor selanjutnya yang menimbulkan disparitas putusan pidana adalah tidak adanya pedoman pemindanaan yang dapat digunakan hakim untuk dipertimbangkan dalam menjatuhkan putusannya khususnya pada perkara tindak pidana korupsi. Perundang-undangan di Indonesia sampai dengan sekarang ini belum memiliki sistem pemidanaan yang bersifat nasional yang di dalamnya mencakup pola pemidanaan dan pedoman pemidanaan. Pola pemidanaan, yaitu acuan/pedoman bagi pembuat undang-undang dalam membuat/menyusun peraturan perundang-undangan yang mengandung sanksi pidana. Istilah pola pemidanaan ini sering juga disebut pedoman legislatif atau pedoman formulatif. Sedangkan pedoman pemidanaan adalah pedoman penjatuhan/penerapan pidana untuk hakim (pedoman yudikatif/pedoman aplikatif). Dilihat dari fungsi keberadaannya, maka pola pemidanaan ini seharusnya ada lebih 
Irfan Ardiansyah, Pengaruh Disparitas Penjatuhan Pidana Terhadap Penanggulangan Tindak....

dahulu sebelum perundang-undangan pidana dibuat, bahkan sebelum KUHP nasional dibuat.

\section{Pengaruh Disparitas Pidana terhadap Pemberantasan Tindak Pidana Korupsi}

Disparitas pidana tidak dapat dilepaskan dari sistem perumusan dan pengancaman pidana dalam perundang-undangan yang ada. Dengan perkataan lain dapat merupakan sumber tidak langsung terjadinya sumber disparitas pidana. Apabila ini dibiarkan akan berakibat timbulnya sikap apatis, sinis dan ketidakpuasan warga masyarakat dengan melakukan main hakim sendiri atau mengadakan reaksi langsung terhadap si pelaku tindak pidana dan aparat penegak hukum, maka undang-undang lah yang menjadi sumber tidak langsung terjadinya disparitas pidana.

Menurut Devi Darmawan (Devi Darmawan, 2010), “disparitas pemidanaan merupakan bentuk dari ketidakadilan yang dilakukan hakim kepada para pencari keadilan. Masyarakat tentunya akan membandingkan putusan hakim secara general dan menemukan bahwa disparitas telah terjadi dalam penegakkan hukum di Indonesia”.

Vonis ringan pada disparitas pidana terhadap sejumlah terpidana kasus korupsi masih jauh dari rasa keadilan masyarakat mengingat korupsi merupakan kejahatan luar biasa karena melanggar hak ekonomi dan hak sosial masyarakat. Itulah sebabnya, penanganan kasus korupsi pun harus secara luar biasa agar dapat memberikan efek jera bagi pelaku dan dapat memenuhi rasa keadilan masyarakat. Aparat penegak hukum, baik penyidik, jaksa penuntut umum, maupun hakim semestinya mengungkap semua kasus korupsi hingga tuntas dan menjatuhkan vonis yang berat yang sesuai dengan rasa keadilan masyarakat.

Dengan hukuman seadanya bagi pelaku kejahatan luar biasa tersebut, tak heran apabila para pelaku tindak pidana korupsi masih dapat bernapas lega meskipun telah divonis. Mereka masih memiliki harta, masih dapat melakukan kegiatan-kegiatan sosial, menyumbang dana ke partai politik, maupun membangun citra baru melalui media massa. Mereka juga 
bisa membayar lawyer yang mahal untuk membela perbuatan laknatnya. Jadi, meski banyak sekali koruptor yang masuk penjara, korupsi tetap berjalan terus (Indonesian Coruption Watch, www.compas.com).

Vonis hakim yang mayoritas memvonis ringan atau sangat ringan telah memberikan keistimewaan pada koruptor itu secara tidak langsung menempatkan koruptor sebagai sosok pemain yang lebih unggul dibandingkan hakim yang menjatuhkan putusan, karena hakim yang menjatuhkan putusan demikian tidak ubahnya sebagai hakim kriminal atau sosok hakim yang mempermainkan hukum.

Bagi hakim yang tidak ingin dirinya dikelompokkan sebagai oknum aparat atau pelaku malapraktik profesi, akhirnya memilih menjatuhhkan vonis berbeda dan istimewa yang bersubstansi melemahkan koruptor atau vomis memberatkan dan berlapis yang berorientasi memutus mata rantai organisasi, meminimalisasi regenerasi koruptor, dan benar-benar menyusahkannya.
3. Konsep Ideal Untuk Meminimalkan Adanya Disparitas Pidana pada Penjatuhan Pidana Tindak Pidana Korupsi Dikaitkan dengan Rasa Keadilan Masyarakat Indonesia

Setelah teridentifikasi sebagai hal yang menyebabkan terjadinya disparitas pemidanaan yang berpengaruh menghalangi pemberantasan korupsi di Indonesia, selanjuntya adalah mencari alternatif solusi untuk mengurangi disparitas pemidanaan.

\section{a. Perlunya Tujuan dan Pedoman} Pemidanaan Dirumuskan/ Diformulasikan dalam KUHP

Telah dilakukan berbagai upaya untuk mengatasi perbedaan dalam pemidanaan dan untuk mencapai "keseragaman" dalam pemidanaan (Parity in sentence). Seiring dengan upaya pembaharuan hukum yang menurut Barda Nawawi Arif telah mulai dari "kakek guru hingga ke cucu murid" (Barda Nawawi Arif, 2011:2), maka masalah 
pemidanaan juga termasuk dalam pembaharuan dimaksud.

Pedoman dan tujuan pemidanaan yang diharapkan/ atau yang seyogyanya diformulasikan dalam sistem pemidanaan bukan untuk mengurangi "kebebasan Hakim" seperti yang termaktub dalam Pasal 4 (3) UU No. 14 Tahun 1970 tentang kekuasaan Kehakiman, melainkan sebagai bentuk tanggung jawab Hakim atas pidana yang dijatuhkan telah sesuai, sepadan dan tepat untuk si pelaku.

Adanya pedoman dan tujuan pemidanaan "sama sekali" bukan menghilangkan kemandirian dan kebebasan Hakim, melainkan memberi dasar filosofis atas pidana yang dijatuhkan dan juga memberikan perlindungan hakim dari ketersesatan akibat prinsip kebebasan.

Pedoman dan tujuan
pemidanaan di samping untuk
memberi arah Hakim dalam
penjatuhan pidana juga dalam
rangka menjaga keseimbangan
dengan kepentingan yang harus
dilindungi dalam Hukum Pidana

juga dalam rangka menjaga keseimbangan tiga kepentingan yang harus dilindungi dalam hukum pidana yaitu: kepentingan negara, pelaku tindak pidana dan korban.

Tujuan dan pedoman dirumuskan terkandung maksud untuk memberi keyakinan pada Hakim atas pidana yang dijatuhkan telah sesuai dengan perbuatan dan karakter pembuat tindak pidana dan juga untuk membantu Hakim dalam memahami makna dari keputusannya apa yang hendak dicapai dengan pidana yang dijatuhkan.

\section{b. Mengkonstruksi Kembali (Rekonstruksi) Pola Pemikiran dan Perilaku Etik Hakim}

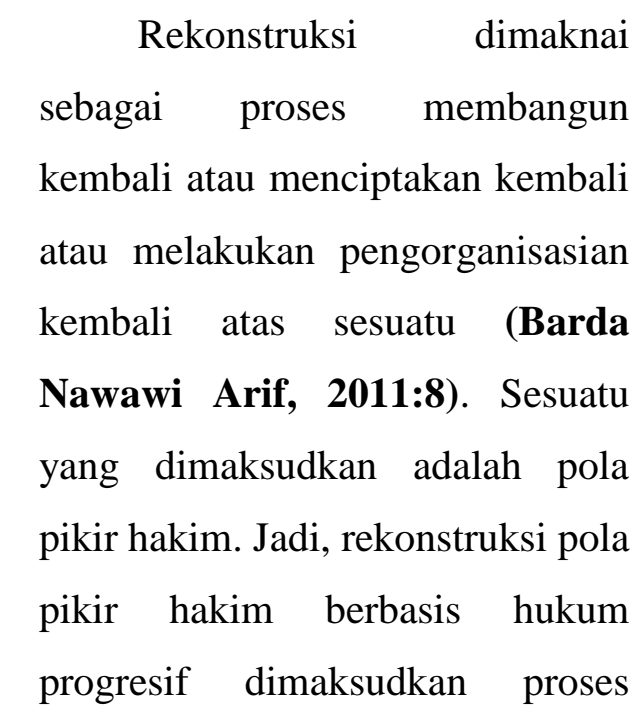


membangun kembali pola pikir hakim dalam menangani suatu perkara (korupsi) yang didasarkan pada asumsi-asumsi, konsepkonsep dan prinsip-prinsip hukum progresif dalam rangka mewujudkan nilai-nilai hukum dalam memutuskan perkara

(Gustav Radbruch, 2011:107108, dan Ridwan, 2011:67-80.). Nilai-nilai hukum itu tersimpan dan juga tersimbolkan dalam judul (irah-irah) di setiap putusan hakim yaitu: "demi keadilan berdasarkan ketuhanan yang maha esa".

Pentingnya suatu konstruksi baru pola pikir hakim bertolak dari kondisi existing (hasil studi) atas penanganan perkara (korupsi) oleh hakim di pengadilan saat ini banyak mengalami kemerosotan atau dapat dibilang kegagalan untuk menghadirkan hukum yang adil, bermanfaat dan melindungi kepentingan masyarakat (social justice). Pola pikir hakim yang bercorak positivistik perlu dibangun kembali (ditata ulang) berdasarkan pola pikir baru yang progresif dalam menyelesaikan problem hukum yang muncul akhir-akhir ini yang semakin kompleks dan rumit, terutama dalam memecahkan masalah korupsi.

Dari uraian di atas dapat ditemukan tujuan dan semangat yang sama antara hukum progresif dengan interessenjurisprudenz, setidak-tidaknya dalam lima hal, yaitu pertama, semangat menempatkan kepentingan dan kebutuhan manusia/rakyat sebagai tujuan utama dari hukum; kedua, kehendak menyelenggarakan hukum secara kreatif; ketiga, pentingnya kepekaan, empati, serta dedikasi dalam penyelenggaraan/penegakan hukum; keempat, kearifan manusia (aparat penegak hukum) menjadi kata kunci pencapaian keadilan; dan kelima, tidak anti peraturan, akan tetapi berusaha terus-menerus memberi makna baru dalam ruang dan waktu yang tepat.

Dalam menangani suatu perkara, hakim tidak dapat lepas dari pilihan nilai-nilai. Hakim akan memilih nilai-nilai yang dianggap penting berdasarkan pemaknaanya atas nilai-nilai tersebut. Dalam 
Irfan Ardiansyah, Pengaruh Disparitas Penjatuhan Pidana Terhadap Penanggulangan Tindak....

praktik, pilihan atas nilai-nilai itu sangat dipengaruhi oleh tingkat kepentingan, kebutuhan hidup, lingkungan dan kebiasan serta karakter pribadi hakim. Dalam praktik kadang terjadi pergeseran pilihan nilainilai oleh hakim yakni dari nilai-nilai ideal atau objektif hukum ke nilai-nilai pragmatik atau subjektif yang dipentingkan dan diutamakan oleh hakim dalam penanganan perkara tertentu. Artinya penanganan suatu perkara dapat menjadisumber komoditi untuk mendapatkan keuntungan pribadi, baik politik maupun ekonomi.

\section{c. Upaya untuk Memutus Perkara yang Bebas Tendensi}

Hakim memikul tanggung jawab yang sangat berat ketika memutus perkara. Putusan yang dijatuhkan hakim tidak hanya dipertanggung-jawabkan kepada para pihak namun juga di hadapan sang khalik. Keberadaan irah-irah "demi keadilan berdasarkan ketuhanan yang maha esa" dalam setiap putusan bukanlah sekedar formalitas bentuk belaka, namun mengandung maksud yang begitu dalam agar putusan hakim harus benar-benar mengandung keadilan yang berdasarkan pada nilai-nilai ketuhanan.

Demi memperoleh putusan yang berkeadilan diperlukan sikap hakim dalam memeriksa dan memutus perkara terbebas dari tendensi atau kecenderungan berpihak kepada salah satu pihak. Pihak yang berkedudukan sebagai penggugat maupun tergugat dalam ranah perdata dan pihak yang berkedudukan sebagai jaksa penuntut dan terdakwa beserta pembelanya harus diperlakukan sama dalam pemeriksaan perkara di persidangan. Hakim harus bersikap tidak berpihak dan memandang sama para pihak, tidak membeda-bedakan orang. Keunggulan dalam ranah sosial karena memiliki jabatan, harta kekayaan, keturunan, bentuk fisik, dan sebagainya tidak berlaku bagi hakim dalam memeriksa dan memutus suatu perkara, baik pidana maupun perdata karena semua orang adalah dipandang sama di hadapan hukum (equality before the law). 


\section{SIMPULAN}

1. Faktor-faktor yang menjadi pertimbangan hakim pada kasus tindak pidana korupsi sehingga menimbulkan disparitas putusan pidana meliputi (1) faktor perundang-undangan; (2) faktor pribadi hakim, seperti misalnya agama, pendidikan, nilai yang dianut dan moralitas serta mentalitas hakim; dan (3) faktor lingkungan yang mencakup faktor politik dan ekonomi;

2. Disparitas pidana tidak berpengaruh terhadap pemberantasan tindak pidana korupsi. Vonis ringan pada disparitas pidana terhadap sejumlah terpidana kasus korupsi masih jauh dari rasa keadilan masyarakat mengingat korupsi merupakan kejahatan luar biasa karena melanggar hak ekonomi dan hak sosial masyarakat;

3. Konsep ideal agar tidak ada lagi disparitas pidana pada penjatuhan pidana tindak pidana korupsi dapat dilakukan dengan cara (1) dibuatnya pedoman pemidanaan yang dapat dijadikan acuan atau ramburambu bagi hakim untuk menjatuhkan sanksi pidana; (2) mengkonstruksi kembali (rekonstruksi) pola pemikiran dan perilaku etik hakim berbasis hukum progresif agar dapat menghadirkan hukum yang adil; dan (3) upaya untuk memutus perkara yang bebas tendensi dan hakim harus bersikap tidak berpihak dan memandang sama para pihak, tidak membeda-bedakan orang, demi memperoleh putusan yang berkeadilan.

\section{SARAN}

1. Kepada Mahkamah Agung disarankan untuk merumuskan pedoman pemidanaan yang dapat digunakan hakim sebagai acuan untuk menjatuhkan putusan sehingga rentang disparitas putusan dapat dikurangi.

2. Mahkamah Agung sebaiknya segera mewujudkan lembaga peradilan yang adil dan bersih dari segala bentuk perbuatan korupsi dan penyalahgunaan 
kekuasaan sehingga pidana yang dijatuhkan oleh lembaga peradilan harus sesuai dengan kadar perbuatan terpidana sesuai dengan undang-undang tanpa pandang bulu atau tebang pilih.

3. Majelis hakim yang mengadili tindak pidana korupsi harus mampu dan memiliki keberanian moral dalam menjatuhkan putusan atau pidana berat khususnya pada kasus-kasus korupsi yang akan menimbulkan kontroversi dalam pandangan masyarakat di Indonesia.

\section{DAFTAR PUSTAKA}

Al.

Wisnubroto, Upaya
Mengembalikan
Kemandirian Hakim Melalui
Pemahaman Realitas
Sosialnya, Jurnal Hukum Pro
Justitia, Tahun XX No. 1
Januari 2013.

Allan Manson, The Law of Sentencing, Irwin Law, 2014.

Barda Nawawi Arif, Pembaharuan Hukum Pidana dalam Perspektif Kajian Perbandingan, Citra Aditya Bakti, Bandung, 2011.

Devi Darmawan, Problematika Disparitas Pidana dalam Penegakan Hukum di Indonesia, dikutip dari http://www.devidarmawan.w ordpress.com.

Esmi Warassih, Pemberdayaan Masyarakat dalam Mewujudkan Tujuan Hukum (Proses Penegakan Hukum dan Keadilan), Pustaka Undip, Semarang, 2013.

Franz Magnis Suseno, Etika Politik: Prinsip-Prinsip Moral Dasar Kenegaraan Modern, Gramedia Pustaka Utama, Jakarta, 2013.

Gustav Radbruch, The Legal Philosophies of Lask, Radbruch, and Dabin, Massachusetts, Harvard University Press, Cambridge, 2011.

Indonesian Coruption Watch, Vonis Korupsi Masih Terlalu Ringan, dikutip dari http://www.compas.com

Kuntoro Mangkusubroto, Pemberantasan Mafia Hukum, UNDP, Jakarta, 2013.

\begin{tabular}{cr} 
Litbang & \multicolumn{2}{c}{ Mahkamah } & Agung, \\
Kedudukan dan & Relevansi \\
Yurisprudensi & untuk \\
Mengurangi & Disparitas \\
Putusan & Pengadilan, \\
Puslitbang Hukum dan & Hum dilan Mahkamah Agung \\
Peradilan & \\
RI, 2011.
\end{tabular}


Irfan Ardiansyah, Pengaruh Disparitas Penjatuhan Pidana Terhadap Penanggulangan Tindak....

Loebby Loqman, HAM dalam HAP, Datacom, Jakarta, 2012.

M. Syamsudin, Konstruksi Baru Budaya Hukum Hakim Berbasis Hukum Progresif, Kencana Prenada Media Group, Jakarta, 2012.

M. Syamsudin, Pemaknaan Hakim tentang Korupsi dan Implikasinya terhadap Putusan: Studi Perspektif Hermeneutika Hukum, Jurnal Mimbar Hukum FH UGM, Vol. 22 No. 4 Oktober 2011.

Muladi dan Barda Nawawi Arief, Dampak Disparitas Pidana dan Usaha Untuk Mengatasinya, Alumra, Bandung, 2012.

Muladi, Independensi Kekuasaan Kehakiman, Penerbit Undip, Semarang, 2011.

Ridwan, Memunculkan Karakter Hukum Progresif dari Asasasas Umum Pemerintahan yang Baik Solusi Pencarian dan penemuan Keadilan Substantif, Jurnal Hukum Pro Justitia, Vol. 27 No. 1 April 2011.

Rizky Argama, Pembukaan Pedoman Perilaku Hakim yang disusun pada tahun 2013 oleh Mahkamah Agung Republik Indonesia, FH UI, Jakarta, 2014.
Satjipto Rahardjo, Penegakan Hukum Progresif, Kompas, Jakarta, 2011.

Sulistyowati Irianto dan Shidarta, Metode Penelitian Hukum Konstelasi dan Refleksi, Yayasan Obor Indonesia, Jakarta, 2012.

Werner Menski, Comparative Law in a Global Context, The Legal Systems of Asia and Africa, Second Edition, Cambridge University Press, New York, 2013.

Undang-Undang Dasar Tahun 1945.

Undang-Undang Nomor 3 Tahun 1971 tentang Pemberantasan Tindak Pidana Korupsi.

Undang-Undang Nomor 31 Tahun 1999 tentang Pemberantasan Tindak Pidana Korupsi.

Undang-Undang Nomor 20 Tahun 2001 tentang Perubahan Atas Undang-Undang Nomor 31 Tahun 1999 tentang Pemberantasan Tindak Pidana Korupsi.

Undang-Undang Nomor 48 Tahun 2009 tentang Kekuasaan Kehakiman. 